\title{
Performance Assessment of Cluster Demonstrations on Chick Pea (Cicer arietinum L.) in Narsinghpur District of Madhya Pradesh, India
}

\author{
Yati Raj Khare*, Prashant Shrivastava and Aashutosh Sharma \\ JNKVV-Krishi Vigyan Kendra, Narsinghpur (M.P.), India \\ *Corresponding author
}

Keywords

Cluster, Chick pea, Benefit cost ratio, Seed yield, JG 63

Article Info

Accepted:

18 May 2019

Available Online:

10 June 2019
A B S T R A C T

A cluster demonstration of improved package of practice of chickpea along with improved variety was conducted in the Narsinghpur district of Madhya Pradesh during rabi 2015-16. Chickpea varieties JG 63, JG 130 and JG 315 (control) were demonstrated. Highest yield was obtained in chickpea variety JG 63 (17.57q /ha) followed by JG $130(15.85 \mathrm{q} / \mathrm{ha})$ and JG 315 (13.6 q/ha). The technology gap in case of JG 63 was the lowest $(493 \mathrm{~kg} / \mathrm{ha})$ compared to that of JG $130(665 \mathrm{~kg} / \mathrm{ha})$ and JG $315(890 \mathrm{~kg} / \mathrm{ha})$. The extension gap revealed that in Narsinghpur district for the increased production of chickpea, there is a lot of scope for the adoption of improved varieties along with improved package of practice. This was well corroborated by the values of Technology Gap index of the best variety JG 63 (in the present case) and the farmer's choice. The Benefit Cost ratio was the highest in case of JG 63 (1:3.47) followed by JG 130 (1:3.24) and JG 315 (1:2.75). Overall the cluster demonstrations revealed that highest seed yield and benefits were obtained in the demonstrations on JG 63 with complete package of practices.

\section{Introduction}

Chickpea (Cicer arietinum L.) is the third largest produced food legume globally after common bean and field pea. With regard to area India ranks first (99.27 lakh - ha) in the world followed by Pakistan (9.50 lakh -ha), Iran (5.94 lakh -ha) and Australia. However, highest productivity of $3759 \mathrm{~kg} / \mathrm{ha}$ is observed in China followed by Israel $(3559 \mathrm{~kg} / \mathrm{ha})$. Chickpea productivity in India is only 995kg/ha (Annual Report DPD 2016-17).It has an extensive geographic distribution and contributes nearly 39 percent to the total pulse production in India (Singh et al., 2013). The major chickpea producing states are Madhya Pradesh, Maharashtra, Rajasthan, Karnataka, Uttar Pradesh and Andhra Pradesh (Annual Report DPD2016-17).

Among the states the highest productivity has been observed in Telangana (1459 kg/ha) followed by Gujarat (1201 kg/ha), Andhra Pradesh (1122 kg/ha), Madhya Pradesh (1105kg/ha) (Annual Report DPD 21016-17) In Madhya Pradesh the Narsinghpur district is one of the major chickpea producing districts. The present demonstration was undertaken with the objective to demonstrate the improved technology of chickpea production 
potential along with the focus of replacement of old varieties by the promising newer high yielding varieties.

\section{Materials and Methods}

A cluster demonstration of improved package of practice of chickpea along with improved variety was conducted in the Narsinghpur district of Madhya Pradesh during rabi 201516. Chickpea varieties viz. JG 63, JG 130 and JG 315 (control) were demonstrated. Demonstrations were conducted in fields of one hundred farmers each of one acre area. Certified seeds were sown. A complete package of practice was demonstrated. Line sowing of chickpea was done with row to row spacing as 9', The seed rate was kept as $75 \mathrm{~kg} /$ ha. The seed was treated with Carbendazym @ 2g/kg seed and Mencozeb @ 1g/kg seed. Soil treatment was done with Rhizobium @ $5 \mathrm{~kg} / \mathrm{ha}$, PSB inoculation @ $5 \mathrm{~kg} / \mathrm{ha}$ and Trichoderma virdae application at the rate of 5 $\mathrm{kg} / \mathrm{ha}$ was done.

A balance dose of fertilizer was applied. Bird perches@50 per ha. was erected in the field. Need based application of insecticide for control of Heliothis was done. Irrigation was given twice during the crop growth period first at bud initiation stage and second time at the pod filling stage. One control plot of farmer practice along with variety JG 315 was also analysed. Crop yield was collected from both the demonstration plots as well as the farmers practice and cost of cultivation was worked out. The data was further used to work out the technology gap, extension gap and technology gap index (Samui et al., 2000) with respect to the highest yield variety observed in the demonstrations.

Technology Gap = Potential YieldDemonstration Yield

Extension gap $=$ Demonstration Yield-farmers Yield
Technology Gap Index $(\%)=($ Technology gap/ Potential Yield) x 100

\section{Results and Discussion}

The three demonstrated varieties showed varying crop yield. Data on pods per plant and crop yield is tabulated below.

\begin{tabular}{|c|c|c|c|}
\hline Parameter & JG 63 & JG 130 & JG 315 \\
\hline $\begin{array}{ll}\text { Seed } & \text { yield } \\
\text { q/ha } & \\
\end{array}$ & 17.57 & 15.85 & 13.6 \\
\hline
\end{tabular}

With regard to seed yield, the variety JG 315 yielded only $13.6 \mathrm{q} / \mathrm{ha}$ as compared to 15.85 q/ha under JG 130 and 17.57 under JG 63. Therefore the chick pea variety JG 63 performed best in terms of seed yield.

This can be contributed to improved variety along with better crop production practices as compared to the Farmers' practice. This is well evident from the fact that the variety JG 315 is very old as compared to JG 130 and JG 63.

\section{Technology gap}

In the current demonstrations the highest productivity has been obtained in the demonstrations under chickpea variety JG 63 (1757 kg/ha).

As per the particulars of the variety JG 63 the yield potential is 2000 to $2500 \mathrm{~kg} / \mathrm{ha}$ (www.jnkvv.org/JNKVV_RESEARCH/RESE ARCH_Crop Gram.aspx).

Thus the technology gap ranged from 243 to $743 \mathrm{~kg} / \mathrm{ha}$ averaging to $493 \mathrm{~kg} / \mathrm{ha}$. This can be attributed to the local soil conditions, climatic factors, soil fertility status and the agricultural practices followed. With the same yield potential the Technology Gap was more in the case JG 315 (890kg/ha) followed by JG 130 $(665 \mathrm{~kg} / \mathrm{ha})$ 


\section{Extension gap}

Under the demonstrations the highest yield was obtained under the variety JG $63(1757 \mathrm{~kg} /$ ha). The farmers choice JG 315 gave the lowest yield $(1360 \mathrm{~kg} / \mathrm{ha})$. Thus the extension gap was observed to be $397 \mathrm{~kg} / \mathrm{ha}$. JG 315 is a very old variety whereas JG 63 is a newer one and has higher disease resistance and higher yield potential. In addition the crop management practices play a major role in the extension gap.

In the present case the newer variety (JG 63) coupled with improved crop management practices attributed to this extension gap of $397 \mathrm{~kg} / \mathrm{ha}$.

It clearly shows that there is ample scope for the farmers of the district to raise the chickpea production - and this can be achieved through adoption of improved crop variety and better management practices.

\section{Technology gap index}

The Technology Gap Index indicates the feasibility of the demonstrated technology at the farmers' fields. The lower the value of the technology gap index more is the feasibility. In case of JG 63 the average technology gap was $493 \mathrm{~kg} / \mathrm{ha}$. The yield potential of JG 63 was $2500 \mathrm{~kg} / \mathrm{ha}$. Therefore the Technology Gap Index comes out to be $19.72 \%$. The same in the case of JG 3015 with respect to JG 63 comes out to be $39.55 \% \quad\{(2250-$ $\left.1360)^{*} 100 / 2250\right\}$. Thus it can be very well said that the Technology Gap index has reduced in case of demonstration of improved crop management practices coupled with improved variety JG 63 as against the Farmer's practice.

\section{Economics of the demonstrations}

The economics of the demonstrations was worked out. The results are as under:

\begin{tabular}{|c|c|c|c|c|}
\hline Variety & $\begin{array}{l}\text { Cost } \\
\text { cultivation } \\
\text { Rs./ha }\end{array}$ & $\begin{array}{ll}\text { Gross } & \text { return } \\
\text { Rs./ha } & \end{array}$ & $\begin{array}{ll}\text { Net } & \text { return } \\
\text { Rs./ha } & \end{array}$ & $\begin{array}{l}\text { Benefit: Cost } \\
\text { ratio }\end{array}$ \\
\hline JG 63 & 24500 & 85000 & 60500 & 1:3.47 \\
\hline JG 130 & 24500 & 79250 & 54750 & $1: 3.24$ \\
\hline JG 315 & 24000 & 66000 & 42000 & $1: 2.75$ \\
\hline
\end{tabular}

The net return under the variety JG 3015 was Rs. 42000/- per ha. This was lower than that obtained under JG 130 (Rs. 54750/- per ha) and JG 63 (Rs. 60500/- per ha). Comparing the benefit vs cost, it was observed that the $\mathrm{B}: \mathrm{C}$ ratio was highest in the variety JG 63 (1:3.47) followed by JG 130 (1:3.24) and JG 3015 (1.275). Thus demonstration of JG 63 accompanied by complete package of practice performed the best and gave highest seed yield and benefits.

In conclusion, the cluster demonstrations revealed that highest seed yield and benefits were obtained in the demonstrations on JG 63 with complete package of practices. The values of Technology Gap, Extension Gap and the Technology Gap Index obtained in the demonstrations clearly indicate that there is ample scope for adoption of improved package of practices in chickpea along with adopting improved varieties. These findings corroborate with the findings of Raghuwanshi et al., 2018 and Singh et al., 2014 corroborate these findings.

\section{References}

Ministry of Agriculture and Farmers Welfare, Directorate of Pulses development, 
Vindhyanchal Bhavan Annual Report 2016-17.

Singh, D., Patel, A. K., Baghel, M. S., Singh, S. K., Singh, A., Singh, A. K. (2014) Impact of front line demonstration on the yield and economics of chickpea (Cicer arietinum L.) in Sidhi district of Madhya Pradesh. Journal of AgriSearch 2014 Vol.1 No.1 pp.22-25 ref.7.

Samui, S.K., Maitra, S., Roy, D.K., Mandal, A.K., and Saha, D. 2000. Evaluation of front line demonstrations on groundnut (Arachis hypogeal L.); Journal of Indian Society of Coastal Agricultural Research, 18(2): 180:183.

Singh, A.K. Manibhushan, Bhatt, B.P., Singh,
K.M., and Upaadhaya, A. (2013) An Analysis of Oilseeds and Pulses Scenario in Eastern India during 205051; Journal of Agricultural Science; Vol. 5, No. 1; 2013. Published by Canadian Center of Science and Education. Pp. 241-249.

Suryawanshi, V.S., Malviya, P. and Meshram, V. (2018) Impact of Frontline Demonstration Programme on the Yield of Chickpea (Cicer arietinum L.) in Mandla District of Madhya Pradesh, India; International Journal of Current Microbiology and Applied Sciences, Volume 7 Number 02 (2018): 10221027.

\section{How to cite this article:}

Yati Raj Khare, Prashant Shrivastava and Aashutosh Sharma. 2019. Performance Assessment of Cluster Demonstrations on Chick Pea (Cicer arietinum L.) in Narsinghpur District of Madhya Pradesh, India. Int.J.Curr.Microbiol.App.Sci. 8(06): 3311-3314.

doi: https://doi.org/10.20546/ijcmas.2019.806.394 